\title{
Sistem Penentuan Sudut Diam Granul Menggunakan Metode Pengolahan Citra Berbasis Android
}

\author{
Abdul Fadlil, Aditiya Dwi Candra \\ Program Studi Teknik Elektro, Fakultas Teknologi Industri, Universitas Ahmad Dahlan \\ Kampus III, Jln. Prof. Dr. Soepomo,S.H. Umbulharjo, Yogyakarta 55161 \\ e-mail: fadlil3@yahoo.com, candraaditya222@gmail.com
}

\begin{abstract}
Granul is a kind of the small pellets it tablets and medical potions component. To measure of the granul qualities which considered by moving time, degree, size of tablet. The degree of granul position has shown better calculated of $28^{\circ}$ to $42^{\circ}$. In past, those was provided using manual calculated, so this study to develop an image processing method it including on smartphone application. The design of this application is done with image processing techniques with the results of calculations. To process the image, by way of calculation. The process of taking images using the camera and. Software used in this study using android studio. The results showed that the average of fixed angles in manual testing for green granules is $35,56^{\circ}$, the red granule is $34,89^{\circ}$, and the yellow granule is $31,18^{\circ}$. The mean value of the silent angle in automated testing for green granules is $34.34^{\circ}$, the red granule is $33,35 \circ$, and the mole granule is $29,80^{\circ}$. The comparison of results between manual and automatic has obtained a green granule of $96,55 \%$, a red granule of $95,56 \%$, and a yellow granule of $95,69 \%$. This research is made easly calculated the granul degrees.
\end{abstract}

Keywords: granul; grayscale; degrees.

\begin{abstract}
Abstrak
Granul merupakan sejenis butiran kecil sebagai bahan dasar untuk membuat tablet dan obat-obatan lainnya. Kualitas granul dapat dilakukan dengan mengukur antara lain waktu alir, sudut diam, dan pengetapan tablet. Nilai sudut diam menunjukkan kualitas granul dengan nilai sudut diam yang baik antara $28^{\circ}$ sampai $42^{\circ}$. Metode untuk menghitung sudut diam selama ini masih dengan eksekusi manual maka pada penelitian ini dikembangkan aplikasi di smartphone dengan teknik pengolahan citra. Perancangan aplikasi ini dilakukan dengan teknik pengolahan citra dengan melakukan perhitungan nilai sudut diam granul dari citra asli red, green, blue konversi ke bentuk grayscale serta ke format citra biner (thresholding) serta akan dilakukan proses cropping untuk memotong bagian tertentu objek citra. Proses pengambilan citra dilakukan menggunakan kamera dan galeri smartphone Android. Software yang dipakai dalam penelitian ini menggunakan Android Studio. Hasil penelitian menunjukkan nilai rata-rata sudut diam dalam pengujian manual untuk granul hijau adalah $35,56^{\circ}$, granul merah adalah $3489^{\circ}$, dan granul kuning adalah $31,18^{\circ}$. Nilai rata-rata dari sudut diam dalam pengujian otomatis untuk granul hijau adalah $34,34^{\circ}$, granul merah adalah $33,35^{\circ}$, dan granul kuning adalah $29,80^{\circ}$. Hasil perbandingan antara manual dan otomatis didapatkan nilai akurasi mencapai $96,55 \%$ untuk granul hijau, granul merah yaitu 95,56\%, dan untuk granul kuning 95,69\%. Diharapkan penelitian ini bisa dibuat lebih akurat sehingga dapat mempermudah dalam perhitungan sudut diam granul.
\end{abstract}

Kata Kunci : granul; skala abu-abu; sudut. 


\section{Pendahuluan}

Granul merupakan gumpalan partikel-partikel yang kecil. Metode Granul kering di bentuk dengan penambahan bahan pengikat ke dalam campuran serbuk, kemudian di kempa menjadi tablet besar (slugging) setelah itu dipecahkan menjadi granul yang lebih kecil. Metode ini baik bahan aktif maupun bahan pengisi harus memliki sifat kohesi supaya masa yang jumlahnya besar dapat di bentuk. Metode ini khususnya untuk bahan-bahan yang dapat di olah dengan metode granul basah karena kepekaannya terhadap uap air atau karena untuk mengeringkan dibutuhkan temperatur yang dinaikkan [2]. Sudut diam adalah salah satu parameter lain dari sifat alir, sudut diam juga dapat dipakai sebagai pembanding uji sifat fisik campuran granul atau serbuk, dengan cara menghitung kotangen dari tinggi kerucut yang dibentuk serbuk atau granul maka akan didapat besar sudut yang membentuknya. Sudut diam antara $28^{\circ}$ sampai $42^{\circ}$ menunjukan sifat alir yang baik atau kualitas granul baik [3].

Dalam perhitungan sudut diam, selama ini masih menggunakan cara manual yaitu dengan menggunakan penggaris untuk menghitung alas dan tinggi tumpukan bubuk granul yang terbentuk dari proses pembentukan sudut diam tersebut. Hasil penelitian ini, akan dirancang suatu alat penentuan sudut diam granul berbasis Android, yaitu dengan menggunakan perangkat smartphone yang dapat meng-capture citra granul yang kemudian diproses dengan metode pengolahan citra diantaranya grayscale, biner, dan cropping dan menampilkan hasil pada layar smartphone, pada layar smartphone akan tertampil tulisan sebagai keterangan bahwa granul termasuk kedalam kualitas baik atau buruk serta muncul nilai sudut diam dari granul tersebut. Dari hasil penelitian ini diharapkan akan memudahkan dalam dunia kefarmasian untuk mempermudah dalam proses perhitungan sudut diam yang biasanya perhitungan dengan cara manual yaitu mengukur tinggi dan alas menggunakan penggaris. Dengan menggunakan aplikas $\mathrm{i}$ ini perhitungan sudut diam akan cepat karena hanya menggambil granul dari kamera maupun galeri smartphone dan terdapat satu tombol proses untuk memproses citra granul.

\section{Metode Penelitian}

\subsection{Dasar Teori}

\subsubsection{Granul}

Granul merupakan gumpalan partikel-partikel yang kecil. Metode Granul kering di bentuk dengan penambahan bahan pengikat ke dalam campuran serbuk, kemudian dikempa menjadi tablet besar (slugging) setelah itu di pecahkan menjadi granul yang lebih kecil. Metode ini baik bahan aktif maupun bahan pengisi harus memliki sifat kohesi supaya masa yang jumlahnya besar dapat di bentuk. Metode ini khususnya untuk bahan-bahan yang tidapat diolah dengan metode granul basah karena kepekaannya terhadap uap air atau karena untuk mengeringkan dibutuhkan temperatur yang dinaikkan [2].

\subsubsection{Sudut Diam}

Sudut diam adalah salah satu parameter lain dari sifat alir, sudut diam juga dapat dipakai sebagai pembanding uji sifat fisik campuran granul atau serbuk, dengan cara menghitung kotangen dari tinggi kerucut yang di bentuk serbuk atau granul maka akan didapat besar sudut yang membentuknya. Sudut diam antara $28^{\circ}$ sampai $42^{\circ}$ menunjukan sifat alir yang baik atau kualitas granul baik [3]. Rumus sudut diam [6] :

$$
\operatorname{Tg} \alpha=\frac{2 \mathrm{~h}}{\mathrm{~d}}
$$

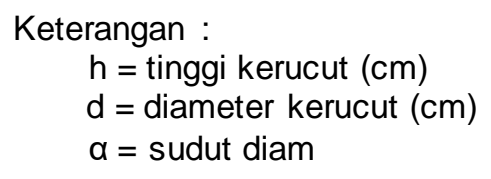

\subsubsection{Citra Warna (True Color)}

Setiap piksel pada citra warna mewakili warna yang merupakan kombinasi dari tiga warna dasar $(R G B=$ red-green-blue $)$. Setiap warna dasar menggunakan penyimpanan 8 bit $=1$ byte, yang berarti mempunyai gradasi sebanyak 255 warna berarti setiap piksel mempunyai kombinasi warna sebanyak. Penyimpanan citra true color didalam memori berbeda dengan citra grayscale. Setiap piksel dari citra grayscale 256 gradasi warna diwakili oleh 1 byte. Sedangkan 1 piksel citra true color diwakili oleh 3 byte yang masing- masing byte merepresentasikan warna merah (red), hijau (green), biru (b/ue) [7]. 


\subsubsection{Grayscale}

Citra skala keabuan memberi kemungkinan warna yang lebih banyak dari pada citra biner, karena ada nilai-nilai diantara nilai minimum (biasanya $=0$ ) dan nilai maksimumnya. Banyaknya kemungkinan nilai dan nilai maksimumnya bergantung pada jumlah bit yang digunakan. Pada citra grayscale ini, format citra disebut skala keabuan karena pada umumnya warna yang dipakai adalah warna hitam sebagai warna minimal dan warna putih sebagai warna minimalnya, sehingga warna antaranya adalah abu-abu [1].

\subsubsection{Biner}

Citra biner (binary image) adalah citra digital yang hanya mempunyai dua nilai derajat keabuan yaitu hitam dan putih. Pada citra biner, setiap titik bernilai 0 atau 1 , masing-masing warna mempresentasikan warna tertentu. Contoh yang paling lazim yaitu warna hitam bernilai 0 dan warna putih bernilai 1 . Setiap titik pada citra biner hanya membutuhkan 1 bit, sehingga setiap byte dapat menampung informasi 8 titik [1].

\subsubsection{Cropping}

Cropping adalah proses pemotongan citra pada koordinat tertentu pada area citra. Untuk memotong bagian dari citra digunakan dua koordinat, yaitu koordinat awal yang merupakan awal koordinat bagi citra hasil pemotongan dan koordinat akhir yang merupakan titik koordinat akhir dari citra hasil pemotongan. Sehingga akan membentuk bangun segi empat yang mana tiap-tiap piksel yang ada pada area koordinat tertentu akan disimpan dalam citra yang baru [4].

\subsection{Alat dan Bahan Penelitian}

\subsubsection{Alat Penelitian}

Alat penelitian yang digunakan terdiri dari hardware dan software. Hardware yang digunakan berupa Smartphone Android dengan versi 6.0 (marsmallow) processor 1.4GHz QuadCore RAM 2 GB layar HD $1280 \times 720$ piksel 5-inci 13 megapiksel, laptop samsung AMD DualCore processor A6-4400M 2.7 GHz 4GB HD 500GB, wadah hitung sudut diam berdiameter 8cm. Software yang digunakan berupa sistem operasi Windows 8.0 Pro, dan Android Studio.

\subsubsection{Bahan Penelitian}

Bahan penelitian yang digunakan adalah 3 jenis granul yaitu granul hijau (ukuran 10/20 mesh), granul merah (ukuran 14/20 mesh), dan granul kuning (ukuran 12/30 mesh). Masingmasing granul diambil citranya sebanyak 30 kali dan totalnya 90 citra. Pada keterangan mesh merupakan ketentuan derajat kehalusan serbuk [5].

\subsection{Perancangan Sistem}

Perancangan sistem terdiri dari diagram blok dan diagram alir yang merupakan tahapan proses pengolahan citra pada saat smartphone Android dalam kondisi aktif. Objek citra akan ditampilkan pada layar smartphone.

\subsubsection{Diagram Blok}

Pada dasarnya prinsip kerja sistem penentuan sudut diam ini adalah dengan memanfaatkan teknik pengolahan citra yaitu citra RGB, citra grayscale, citra biner, dan cropping. Citra granul diambil menggunakan kamera smartphone android, selanjutnya akan dilakukan proses cropping untuk memotong sebagian objek dengan background, setelah cropping selesai akan ditampilkan di image view aplikasi yang merupakan citra asli hasil cropping. Untuk mengetahui nilai sudut diam dan kualitas granul maka dipilih tombol proses. Pada tombol proses akan mengubah citra asli hasil cropping menjadi bentuk grayscale serta ke bentuk biner. Citra biner akan dimanfaatkan untuk mendapatkan nilai alas dan tinggi dari citra granul. Dimana, citra biner hanya terdapat 2 komponen warna saja yaitu hitam dan putih. Hitam ditentukan sebagai alasnya dan putih sebagai tinggi selanjutnya akan dimasukan ke dalam persamaan sudut diam. Prinsip kerja sistem dapat dilihat pada Gambar 1

$$
\alpha=\operatorname{arctg}\left(2^{*} \text { tinggi/alas }\right)
$$




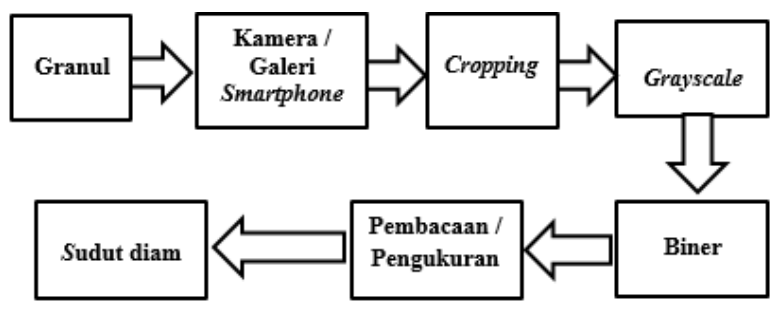

Gambar 1. Diagram blok aplikasi penentuan sudut diam granul

\subsubsection{Diagram Alir}

Diagram alir yang ditunjukan pada Gambar 2 merupakan tahapan proses sistem penentuan sudut diam granul menggunakan metode pengolahan citra berbasis Android.

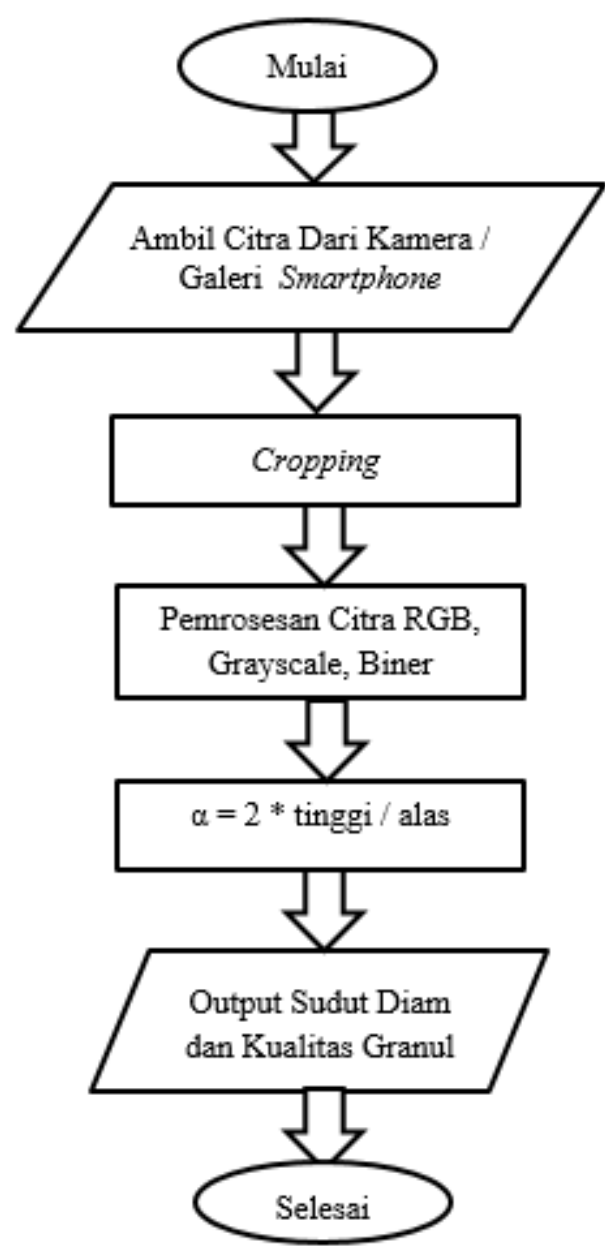

Gambar 2. Diagram alir aplikasi penentuan otomatis sudut diam granul

Keterangan diagram alir aplikasi penentuan otomatis sudut diam granul Gambar 2 yaitu :

1. Mulai pengambilan citra granul menggunakan kamera atau galeri di s martphone

2. Selanjutnya dilakukan proses cropping dengan memotong bagian tertentu citra

3. Hasil cropping dilakukan proses grayscale (keabuan) dan konversi dari grayscale menjadi biner (thresholding).

4. Setelah proses biner selesai maka dapat ditentukan sudut diamnya berdasarkan persamaan (2)

5. Output sudut citra berupa nilai sudut diam granul dan kualitas granul hasil eksekusi sistem.

6. Selesai dari hasil perhitungan otomatis sudut diam dengan aplikasi smartphone. 


\section{Hasil dan Pembahasan}

Pada pembahasan ini akan menampilkan hasil pengujian terhadap perhitungan manual dengan perhitungan otomatis dalam penentuan sudut diam granul.

\subsection{Perhitungan Manual}

Cara perhitungan sudut diam secara manual terlihat pada Gambar 3.

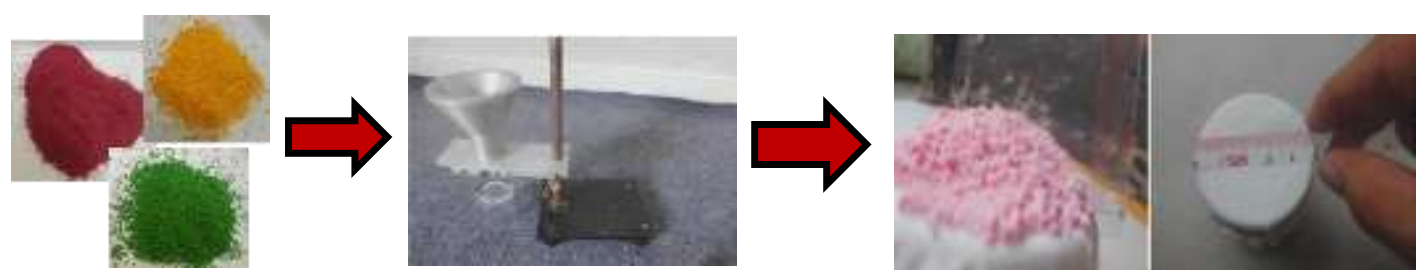

Gambar 3. Cara perhitungan manual

Gambar 3 merupakan cara perhitungan sudut diam secara manual. Granul akan dimasukan kedalam sebuah wadah berbentuk corong, kemudian granul akan turun dari lubang wadah tersebut dan membentuk gundukan. Gundukan granul selanjutnya dilakukan pengukuran menggunakan penggaris untuk menentukan tinggi dan alasnya. Hasil tinggi dan alas kemudian dimasukan kedalam rumus sudut diam.

\subsection{Perhitungan Otomatis}

Cara perhitungan sudut diam secara otomatis terlihat pada Gambar 4.

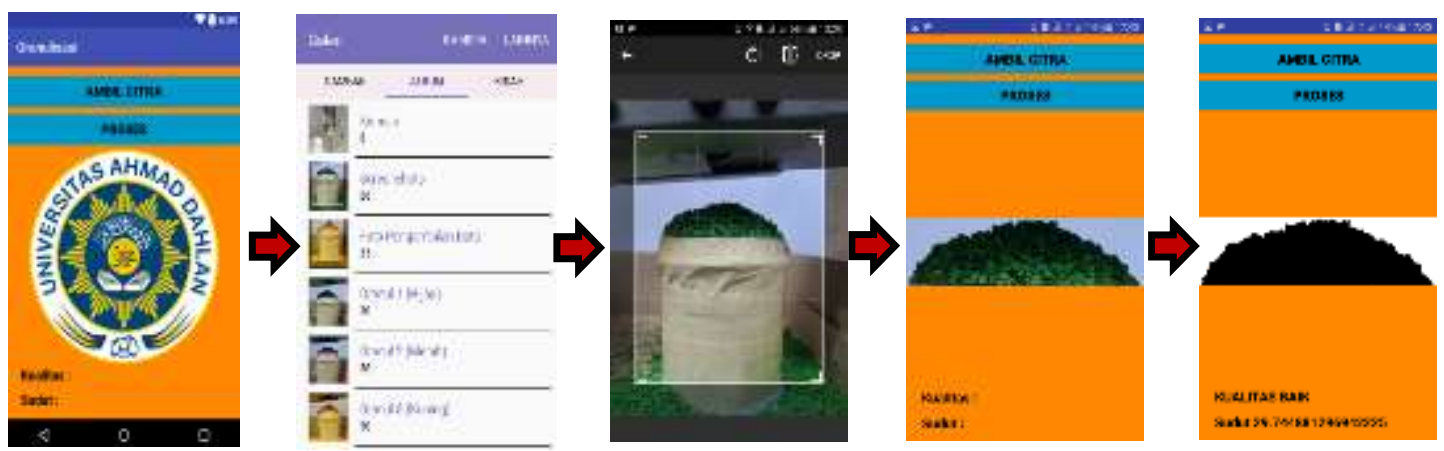

Gambar 4. Cara perhitungan otomatis

Gambar 4 merupakan cara perhitungan sudut diam secara otomatis. Pengoperasiannya dengan memilih tombol ambil citra, kemudian pilih dari kamera atau galeri. Selanjutnya akan masuk ke proses cropping untuk mengambil sebagian citra yang akan di proses. Hasil cropping akan ditampilkan di image view aplikasi. Untuk mengetahui kualitas dan nilai sudutnya, pilih tombol proses dan hasil sudut diam serta kualitas akan muncul. Hasil tersebut di ambil dari citra biner dengan menentukan tinggi dan alasnya dengan satuan piksel. Warna hitam sebagai alas dan warna putih sebagai tinggi.

\subsection{Hasil Perbandingan Sistem}

Hasil perbandingan perhitungan otomatis dengan perhitungan manual terlihat pada Tabel 1.

Tabel 1. Hasil perbandingan sistem

\begin{tabular}{cccc}
\hline Jenis Citra & Hitung Manual & Hitung Otomatis & $\begin{array}{c}\text { Akurasi } \\
(\%)\end{array}$ \\
\hline Granul Hijau & $35,56^{\circ}$ & $34,34^{\circ}$ & 96,55 \\
\hline Granul Merah & $34,89^{\circ}$ & $33,35^{\circ}$ & 95,56 \\
\hline Granul Kuning & $31,18^{\circ}$ & $29,80^{\circ}$ & 95,69 \\
\hline
\end{tabular}


Tabel 1 merupakan hasil perbandingan perhitungan otomatis dengan perhitungan manual. Terdapat 3 jenis granul yaitu granul hijau, granul merah dan granul kuning. Pada granul hijau nilai hitung manual menunjukan sudut $35,56^{\circ}$ dan hitung otomatis $34,34^{\circ}$ serta akurasinya 96,55 $\%$. Granul merah nilai hitung manual menunjukan sudut $34,89^{\circ}$ dan hitung otomatis $33,35^{\circ}$ serta akurasinya $95,56 \%$. Granul kuning nilai hitung manual menunjukan sudut $31,18^{\circ}$ dan hitung otomatis $29,80^{\circ}$ serta akurasinya $95,69 \%$. Hasil hitung manual, hitung otomatis dan akurasi tersebut merupakan hasil dari nilai rata-rata citra granul sebanyak 30 citra untuk 1 jenis granul. Jadi untuk 1 granul mempunyai 30 sample citra yang terdapat di galeri smartphone.

\section{Kesimpulan}

Berdasarkan hasil penelitian dan pembahasan yang telah dilakukan mengenai sistem penentuan sudut diam granul menggunakan metode pengolaha citra berbasis android, penelitian ini telah berhasil merancang dan mengaplikasikan perhitungan secara otomatis dengan menggunakan teknik pengolahan citra, penelitian ini juga telah berhasil memunculkan nilai sudut diam dan kualitas granul serta membandingkan hasil hitung manual dan hitung otomatis untuk mendapatkan tingkat akurasi dari aplikasi yang telah dibuat. Berdasarkan hasil pengujian, granul hijau nilai hitung manual menunjukan sudut $35,56^{\circ}$ dan hitung otomatis $34,34^{\circ}$ serta akurasinya $96,55 \%$. Granul merah nilai hitung manual menunjukan sudut $34,89^{\circ}$ dan hitung otomatis $33,35^{\circ}$ serta akurasinya $95,56 \%$. Granul kuning nilai hitung manual menunjukan sudut $31,18^{\circ}$ dan hitung otomatis $29,80^{\circ}$ serta akurasinya $95,69 \%$.

\section{Referensi}

[1] Achmad, B. \& Firdausy, K. (2005). Pengolahan Citra Digital menggunakan DELPHI. Yogyakarta: Ardi Publishing.

[2] Ansel, H.C. (1999). Pengantar Benluk Sediaan Farmasi, diterjemahkan oleh Ibrahim, F. Jakarta: Universitas Press.

[3] Cartensen, J. T. (1997). Pharmaceutics of Solid and Solid Dosage Forms. New York: Publication Jhon Wiley and Sons, 209-214.

[4] Informatika. (2013). Operasi Cropping. Diperoleh dari: http://informatika.web.id/operasicropping.html. (Diakses pada 29 Juli 2017).

[5] Muhlis, M. (2013). Diktat Kuliah Farmasetika. Yogyakarta: Faruad-jogja. Sugihartini, N.,Setianto, A.B., \& Efiana, N.A. (2013). Formulasi Dan Teknologi Sediaan Padat. Yogyakarta: Laboratorium Teknologi Farmasi Universitas Ahmad Dahlan.

[6] Sutoyo, T., Mulyanto, E., Suhatono, V., Nurhayati, O. D., \& Wijanarto. (2009). Teori Pengolahan Citra Digital. Semarang : Penerbit Andi. 